\title{
Proton Değişim Membran Yakıt Hücreleri: Termodinamiği, Bileşenleri ve Uygulama Alanları
}

\author{
Gamze Karanfil
}

\section{ÖZ}

Proton değişim membran (PEM) yakıt hücreleri yakıtta depolanan kimyasal enerjiyi doğrudan ve verimli bir şekilde elektrik enerjisine dönüştüren, tek yan ürün olarak suyun oluştuğu; enerji kullanımımızı, kirletici emisyonları ve fosil yakıtlara bağımlılığı azaltma potansiyeline sahip bir teknolojidir. Uzun yıllardır süren araştırma ve geliştirme çalışmaları neticesinde ticarileşmeye başlayan PEM yakıt hücrelerinin geleneksel teknolojilere alternatif olabilmesi için hala aşılması gereken zorluklar vardır. Sürdürülebilirlik, dayanıklılık ve maliyet gibi zorlukların aşılabilmesi için PEM yakıt hücrelerinin çalışma prensibinin, termodinamiğinin ve araştırma çalışmaları hala devam eden bileşenlerinin görevlerinin detaylı olarak irdelenmesi; ayrıca potansiyel uygulama alanlarının bilinerek geliştirme çalışmalarının bu yönde devam etmesi gerekmektedir. Yapılan derleme çalı̧̧masında, PEM yakıt hücresinin teorisinin detaylı bir biçimde incelenmesinin yanı sıra; dünya literatüründe devam eden çalışmalar ile ilgili bilgi verilmiş ve keşfediliş tarihinden bu yana olan uygulama alanları özetlenmiştir.

Anahtar Kelimeler: Enerji, yenilenebilir enerji kaynakları, proton değiş̧im membran yakıt hücreleri

\section{Proton Exchange Membrane Fuel Cells: Thermodynamics, Components and Applications}

\begin{abstract}
Proton exchange membrane (PEM) fuel cells are those that form the water as the only by-product that directly and efficiently converts the chemical energy stored in the fuel into electrical energy; it is a technology that has the potential to reduce our energy use, pollutant emissions and dependence on fossil fuels. PEM fuel cells, which have started commercializing as a result of long years of research and development, still have difficulties to overcome to be an alternative to traditional technologies. In order to overcome the difficulties such as sustainability, durability and cost, the detailed study of PEM fuel cells' working principle, thermodynamics, and the tasks of the ongoing research studies; In addition, potential development areas should be known and development activities should continue in this direction. In the compilation study, in addition to the detailed examination of the theory of PEM fuel cell; information on ongoing studies in the world literature has been given and the areas of application that have been in place since the discovery date are summarized.
\end{abstract}

Keywords: Energy, renewable energy sources, proton exchange membrane fuel cells

\footnotetext{
İletişim Yazarı

Geliș/Received

Kabul/Accepted

21.01 .2020

06.04.2020

Dr. Karamanoğlu Mehmetbey Üniversitesi, Mühendislik Fakültesi, Enerji Sistemleri Mühendisliği, Karaman -

gamzekaranfil86@gmail.com

ORCID: 0000-0002-7941-9853
} 


\section{GİRIŞ}

İnsan nüfusunun hızlı artışı ve sanayinin gün geçtikçe gelişmesi nedeniyle küresel enerji tüketimi ve buna bağlı olarak enerji talebi hızla artmaktadır [1]. Bugüne kadar, enerji ihtiyaçları fosil yakıtların yanmasıyla sağlanmış ve bu hava kirliliğini, özellikle kentsel alanda $\mathrm{CO}_{2}$ gibi sera gazlarının emisyonunu artırmıştır [2]. Bunun yanı sıra, fosil yakıt rezervleri sınırlıdır. Bu problemler göz önüne alındığında iki seçenek ortaya çıkmaktadır: ya mevcut fosil yakıt kullanım tesisleri optimize edilecek ya da yenilenebilir enerji kaynaklarının kullanımının yaygınlaştırılması sağlanacaktır. Fosil yakıtların sınırlı rezerv durumu dikkate alındığında ikinci seçeneğin daha sürdürülebilir olduğu açıkça görülmektedir. Güneş, rüzgâr, jeotermal gibi yenilenebilir enerji kaynakları, dünya enerji arzındaki artan kapasite ve oranla son yıllarda hak ettiği daha fazla önem ve yatırıma kavuşmaktadır. Bununla birlikte, yenilenebilir enerji kaynaklarının aralıklı doğası yani sürekli olmayışı uygulama beklentilerini kısıtlamaktadır $[3,4]$.

Yakıt hücreleri, çevre dostu güç kaynakları ile ilgili sorunu hafifletmek ve diğer yenilenebilir enerji kaynaklarının sürdürülebilirlik problemini ortadan kaldırmak için en güçlü alternatiftir. Yakıt hücresi teknolojisinin geleneksel güç üretim cihazlarıyla karşılaştırıldığında yüksek verime sahip olması, özellikle ulaşım ve taşınabilir cihazlarda kullanımının öne çıkmasını sağlamıştır [5]. Yakıt hücreleri, -yakıt olarak hidrojen kullanıldığında- sıfır emisyonlu ve yüksek enerji dönüşümlü elektrik enerjisi üretir ve yan ürün olarak sadece su çıkar. Yakıt hücreleri kullanılan elektrolitin tipine göre sınıflandırılır. Hali hazırda incelenmekte olan yakıt hücreleri arasında proton değişim membran yakıt hücreleri (PEMYH), alkali yakıt hücreleri (AYH), katı oksit hücreleri (KOYH), fosforik asit yakıt hücreleri (FAYH) ve erimiş karbonat yakıt hücreleri (EKYH) bulunmaktadır. PEM yakıt hücrelerinde yakıt olarak hidrojen yerine metanol kullanıldığında, PEMYH doğrudan metanol yakıt hücresi (DMYH) olarak adlandırılmaktadir [6].

\section{PROTON DEĞİŞIM MEMBRAN (PEM) YAKIT HÜCRESI}

\section{1 Çalışma Prensibi ve Termodinamiği}

Yakıt hücresi çeşitleri arasında PEM yakıt hücresi, en yüksek enerji yoğunluğuna sahip olanıdır. 60 ile $80{ }^{\circ} \mathrm{C}$ arasındaki düşük çalışma sıcaklığı nedeniyle, PEM yakıt hücreleri hızlı başlama özelliğine sahip olup, güç talebindeki değişikliklere iyi yanıtlar sağlayabilmektedir. PEM yakıt hücrelerinin diğer avantajları ise düşük ağırlık ve hacme sahip olmalarıyla birlikte yüksek güç yoğunluğu içermeleridir. PEM yakıt hücrelerinin bu avantajları onları, ulaşım alanındaki uygulamalar, taşınabilir cihazlar ve küçük sabit uygulamalar için gelecek vadeden adaylar haline getirmektedir [7].

PEM yakıt hücresinin şematik gösterimi Şekil 1'de verilmiştir. PEM yakıt hücresinde 


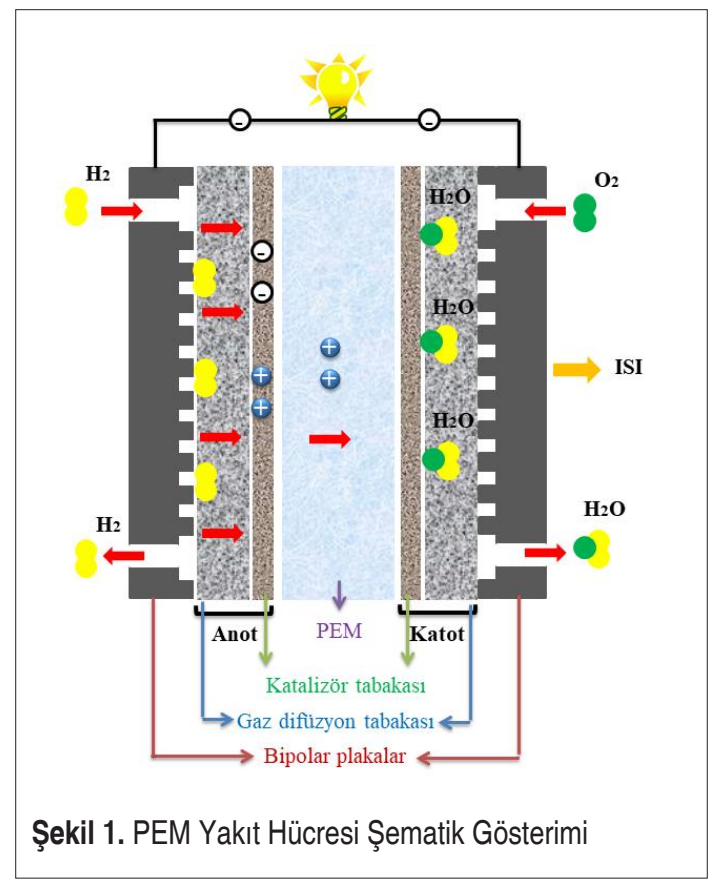

anot tarafina hidrojen (veya başka bir yakıt) verilirken, katot tarafina oksijen (saf oksijen veya hava) verilir.

Anotta hidrojen elektronlara ve protonlara ayrılırken bu işlem bir katalizör [örneğin, platin (Pt) içeren bileşikler] varlığında gerçekleştirilmektedir. Üretilen protonlar, proton iletken elektrolitten (membran) geçerken elektronlar dış devreden dolaşır; bağlı bir cihaza güç verir ve katoda ulaşarak oksijeni indirger. Katotta protonlar oksijen ile birleşerek su oluşturur [8]. Yakıt olarak hidrojen gazı kullanıldığında PEM yakıt hücresindeki anot ve katot reaksiyonları aşağıda verildiği gibidir:

Anot reaksiyonu: $\mathrm{H}_{2} \rightarrow 2 \mathrm{H}^{+}+2 \mathrm{e}^{-}$

Katot reaksiyonu: $\mathrm{O}_{2}+4 \mathrm{H}^{+}+4 \mathrm{e}^{-} \rightarrow 2 \mathrm{H}_{2} \mathrm{O}$

Toplam reaksiyon: $2 \mathrm{H}_{2}+\mathrm{O}_{2} \rightarrow 2 \mathrm{H}_{2} \mathrm{O}+1 \mathrm{~S} 1+$ elektrik enerjisi

PEM yakıt hücresinden elektrik enerjisi (yararlı iş) sadece akım çekildiğinde elde edilebilir, fakat gerçek hücre potansiyeli $\left(V_{\text {hücre }}\right)$ tersinmez kayıplar nedeniyle termodinamik potansiyelden $(E)$ daha düşüktür. Akım geçtiği zaman, termodinamik potansiyelde meydana gelen sapma hücre tarafından gerçekleştirilen elektriksel işe karş1lık gelir. Denge değerinden sapma polarizasyon olarak adlandırılır ve $\eta$ ile gösterilir. Polarizasyonlar birincil olarak; aktivasyon polarizasyonu $\left(\eta_{a k t}\right)$, ohmik polarizasyonu $\left(\eta_{\text {ohm }}\right)$ ve difüzyon polarizasyon $\left(\eta_{d i f}\right)$ 'ndan kaynaklanmaktadır. 
Bu nedenle, tek bir hücrenin voltaj ifadesi şu şekilde verilebilir:

$$
V_{\text {hücre }}=E+\eta_{\text {akt }}+\eta_{\text {ohm }}+\eta_{\text {dif }}
$$

Toplam reaksiyonda verilen $\mathrm{H}_{2}+\mathrm{O}_{2}$ kimyasal reaksiyonların tersinir termodinamik potansiyeli Nernst denklemiyle verilir:

$$
E=E^{0}-\left[\left(\frac{R T}{n F}\right) \ln \left(\frac{P_{\mathrm{H}_{2} \mathrm{O}}}{P_{\mathrm{H}_{2}} \sqrt{P_{\mathrm{O}_{2}}}}\right)\right]
$$

Nernst denkleminde $R$ gaz sabiti (8,314 J/mol K), $T$ hücre sıcaklığg $(\mathrm{K}), n$ elektron sayıs1, $F$ Faraday sabiti $(96487 \mathrm{C} / \mathrm{mol}), P_{H 2 O}, P_{H 2}$ ve $P_{O 2}($ atm $)$ de sirasiyla suyun, hidrojenin ve oksijenin kısmi basıncıdır. Ayrıca $E^{0}$ elektrokimyasal reaksiyonun tersinir standart potansiyeli olarak tanımlanır ve standart şartlardaki Gibbs serbest enerjisindeki değişim $\left(\Delta \mathrm{G}^{0}\right)$ ifadesi kullanılarak şu şekilde verilir [9]:

$$
E^{0}=-\frac{\Delta G^{0}}{n F}
$$

Aktivasyon polarizasyonu, elektrokimyasal reaksiyon sırasında katalizör tabakaları, yük kinetiği, elektron ve protonun elektrot-elektrolit üstünden geçişinden kaynaklanır [10]. Başka bir deyişle, elektron transfer reaksiyonu devam ederken elektrot potansiyelinin bir kısmı kaybolur. Aktivasyon polarizasyonu, elektrokimyasal reaksiyonların doğasıyla doğrudan ilişkilidir ve reaksiyonun akımın talep ettiği oranda ilerlemesi durumunda aktivasyon enerjisinin büyüklüğünü temsil eder. Bir PEM yakıt hücresinin elektrotlarında meydana gelen aktivasyon polarizasyonunu veren denklem Tafel denklemi olarak bilinir [9].

$$
\eta_{a k t}=\left(\frac{R T}{\alpha n F}\right) \ln \left(i_{0}\right)+\left(\frac{R T}{\alpha n F}\right) \ln (i)
$$

Ohmik polarizasyonu, hücredeki elektriksel direnç kayıplarından kaynaklanır. Bu dirençler elektronların bipolar plakaya geçişinden kaynaklanır ve hemen hemen tüm yakıt hücresi bileşenlerinde bulunabilir. Membrandaki iyonik direnç, elektrotlardaki iyonik ve elektronik direnç, gaz difüzyon tabakalarındaki elektronik direnç, bipolar plakalar ve bağlantı uçlarındaki elektronik direnç ohmik polarizasyona neden olur [10]. Ohmik polarizasyonu, Ohm Kanunu gibi denklemler kullanılarak ifade edilebilir [9]:

$$
\eta_{\text {ohm }}=-i R^{i c ̧}
$$

Difüzyon polarizasyonu, yüksek akım yoğunluklarında reaktanlar ve ürünler arasındaki kütle aktarım sınırlaması nedeniyle ortaya çıkar ve hem anot hem de katot elektrot yüzeyine etki eder[10]. Elektrot reaksiyonları, akım akışını devam ettirmek için sabit bir reaktif kaynağı gerektirir. Difüzyon sınırlamaları bir reaktantın kullanılabilirliğini azalttığında, mevcut reaksiyon enerjisinin bir kısmı kütle transferini yürütmek için kullanılır, böylece çıkış voltajında karşılık gelen bir kayıp meydana gelir. Bir reaksiyon ürünü elektrot yüzeyinin yakınında birikir ve difüzyon yollarını tıkarsa 
veya reaksiyona giren maddeleri seyreltirse benzer problemler gelişebilir. Difüzyon polarizasyonu, aşağıdaki gibi ifade edilebilir [9]:

$\eta_{\text {dif }}=\left(\frac{R T}{n F}\right) \ln \left(\frac{i_{l}-i}{i_{l}}\right)$

PEM yakıt hücresinin termodinamik verimliliği $\left(E_{P E M}\right)$, çıkan gücün $(W)$ hidrojen tüketim miktarı $\left(m_{H 2}\right)$ ile hidrojenin alt 1 sıl değerine $\left(L H V_{H 2}\right)$ oranı olarak verilebilir:

$$
E_{P E M}=\frac{W}{m_{H_{2}} \cdot L H V_{H_{2}}}
$$

Belirli bir çıkış akımı için yığının çıkış voltajı belirlendiğinde, çıkış gücü şu şekilde bulunur:

$W=I V_{\text {hücre }}$

Çıkış akımı, hidrojen kütle akış hızı ile şu şekilde ilişkilidir:

$$
m_{H_{2}}=\frac{I \cdot M W_{H_{2}}}{2 F}
$$

Böylece PEM yakıt hücresinin termodinamik verimliliği aşağıdaki gibi basitleştirilebilir [9]:

$$
E_{P E M}=\frac{2 V_{h u ̈ c r e} F}{M W_{H_{2}} \cdot L H V_{H_{2}}}
$$

\subsection{Bileşenleri}

PEM yakıt hücresinde; çok fazlı akışlar, elektrokimyasal reaksiyonlar, yük taşıma ve 1Sı transferi gibi fenomenlerin aynı anda gerçekleşmesi karmaşık bir yapıya sahip olmasına neden olmaktadır. Yakıt hücresinin çalışması sırasında gerçekleşen çoklu fizik olgusunun temelleri ve bunların malzeme özellikleriyle olan ilişkisi oluşan problemlerin üstesinden gelmek için kritik öneme sahiptir. Tüm bu olayların gerçekleştiği yakıt hücresi bileşenleri -membran, katalizör ve gaz difüzyon tabakasından oluşan membran elektrot bileşkesi ve gaz akış kanallarını içerisinde bulunduran bipolar plakalar- şeklinde verilebilir [11].

\subsubsection{Proton değişim membranı}

Proton iletimi, PEM yakıt hücreleri için temel fonksiyondur ve genellikle yakıt hücresi kullanımı için membranları değerlendirirken dikkate alınan ilk özelliktir. Direnç kaybı, membranın iyonik direnci ile orantılıdır ve özellikle yüksek akım yoğunluğunda gerekli performans için yüksek proton iletkenliği gereklidir. Moleküler düzeyde, hidratlı polimerik matrislerdeki proton taşınması genel olarak iki ana mekanizmadan biri ile tarif edilir. Bunlardan birincisi 'proton atlamalı' olarak da tarif edilebilen 'Grotthus mekanizması'; ikinci ise suyun bir taşıma aracı olarak işlev gördüğü 'difüzyon mekanizması'dır. 
Proton atlatma mekanizmasında protonlar, bir hidrolize iyonik bölgeden $\left(\mathrm{SO}_{3}{ }^{-} \mathrm{H}_{3} \mathrm{O}^{+}\right)$ membran boyunca bir diğerine atlarlar. Anot hidrojen oksidasyonu sonucu oluşan proton su molekülüne yapışarak geçici bir hidronyum iyonu oluşturur ve aynı hidronyum iyonundan farklı bir proton diğer su molekülüne atlar. Bu mekanizmada, iyonik kümeler su varlığında şişmiş ve proton aktarımı için süzülme mekanizmasını oluşturmuştur. Proton atlatma mekanizmasının, Nafion gibi perflorlanmış sülfonik asit membranlarının iletkenliğine çok az bir katkısı vardır.

İkinci mekanizma ise difüzyon mekanizmasıdır. Bu mekanizmada, hidratlanmış proton $\left(\mathrm{H}_{3} \mathrm{O}^{+}\right)$, elektrokimyasal fark nedeniyle sulu ortamda difüze olur. Difüzyon mekanizmasında suya bağlı protonlar $\left(\mathrm{H}^{+}\left(\mathrm{H}_{2} \mathrm{O}\right)_{\mathrm{x}}\right)$; elektro-ozmotik sürükleme sonucunda bir veya daha fazla su molekülünü membran boyunca taşır ve kendilerini onlarla birlikte transfer eder. Difüzyon mekanizmasının oluşumunun ana işlevi, proton değişim membrandaki polimerik zincirler içindeki serbest hacimlerin varlığıdır ve bu da hidratlanmış protonların membrandan aktarılmasına izin verir [12].

Yakıt hücresindeki proton değişim membranın; yüksek proton iletkenliği, elektrokimyasal ve kimyasal kararlılık, hidrolitik ve termal kararlılık, mükemmel su tutumu, iyi kimyasal özellikler, reaktantlara karşı düşük geçirgenlik, yakıt geçişine karşı direnç, iyi mekanik stabilite ve dayanıklılık, hızlı elektrot kinetiğini kolaylaştırma, farklı yakıtlara uygunluk ve düşük maliyet gibi özelliklere sahip olması istenmektedir [1].

$\mathrm{Bu}$ özelliklerinin yanı sıra, membranın su yönetimi ve kalınlığı da yakıt hücrelerinin genel performansında önemli rol oynamaktadır.

Yakıt hücresi performansındaki ilerlemeler, membran teknolojisindeki ilerlemeler ile yakından ilişkilidir. Perflorosülfonik asit membranları (Nafion, Dow, Aquivion, Aciplex-S ve Flemion gibi) yüksek proton iletkenlikleri, iyi kimyasal ve mekanik kararlılıkları nedeniyle en yaygın şekilde kullanılan ve ticarileştirilen proton değişim membranlarıdır. Perflorosülfonik asit membranlar karbon-flor ana zincirine, sülfonik grup içeren yan halkaların bağlanmasıyla oluşmuştur. Bunların arasında 1966 yılında Dupont firması tarafından geliştirilen Nafion membran düşük sıcaklıklarda sergilediği yüksek proton iletkenliği ve iyi kimyasal kararlılığı nedeniyle en sık kullanılan membrandır $[13,14]$. Nafion membranın kullanım ömrü $80^{\circ} \mathrm{C}^{\prime}$ de 60000 saate ulaşabilmektedir ve tamamen sulu ortam şartlarında $0.10 \mathrm{Scm}^{-1}$ gibi yüksek proton iletkenliği göstermektedir [15]. Mükemmel proton iletkenliği ve iyi bir kararlılığa sahip olmasına rağmen Nafion membran; yüksek maliyet, yüksek metanol geçirgenliği, dehidrasyon sorunu ve $80^{\circ} \mathrm{C}$ 'den daha yüksek sıcaklıklarda düşük proton iletkenliği gibi büyük dezavantajları nedeniyle ticari uygulamalarda problem yaratmaktadır. Özellikle yüksek sıcaklıklarda yüksek proton iletkenliği sağlamak ve su yönetimini iyileştirmek için Nafion; inorganik oksitlerle $\left(\mathrm{TiO}_{2}, \mathrm{SiO}_{2}, \mathrm{ZrO}_{2}\right.$ gibi), killerle (simektit, montmorillonit gibi), zeolit ve heteropoliasitlerle katkılandırılarak kompozit membran halinde üretilmiştir. Ayrıca Nafion, su yönetimini iyileştirmek ve metanol geçirgenliğini azaltmak için polimerlerle (polianilin (PANI), sülfonlanmış polietereterketon (sPEEK), poli- 
akrilonitril (PAN) gibi) karıştırılarak karışım membran şeklinde geliştirilmiştir [12]. Daha düşük maliyetle membran üreterek ticarileştirmeyi kolaylaştırmak amacıyla, sülfonlanmış aromatik hidrokarbon polimerlerin proton değişim membran üretiminde kullanılmasıyla ilgili bir çok çalışma yapılmış ve yapılmaya devam etmektedir. En çok kullanılan polimerler; sülfonlamış poli (eter eter keton) (sPEEK), sülfonlanmış poli (eter sülfon) (sPES), sülfonlanmış polisülfon (sPSU), sülfonlanmış poli (arlen eter sülfon) (sPAES), sülfonlanmış poli (arlen eter ketone) (sPAEK) ve sülfonlanmış poliimid (sPI) olarak verilebilir. Bu polimerler saf halde üretildiği gibi kompozit ve karışım membran olarak da üretilmiş ve yakıt hücresi performansları incelenmiştir $[13,14,16]$.

\subsubsection{Katalizör tabakası}

Katalizör tabakası, anottaki hidrojen oksidasyon reaksiyonu (HOR) ve katottaki oksijen indirgeme reaksiyonunun (ORR) gerçekleştiği yerdir. PEM yakıt hücrelerinde genellikle iki yakıt kullanılmaktadır. Bunlardan birincisi; hidrokarbon veya oksijenli hidrokarbonların işlenmesiyle üretilmiş ve 'reform edilmiş' olarak adlandırılmış $\mathrm{H}_{2}$, ikincisi ise metanoldür. Bu iki yakıt dışında etanol, formaldehit veya formik asit gibi yakıtlar üzerinde de çalışılmış ama henüz pratik kullanıma geçilmemiştir. PEM yakıt hücresinin anot elektrotunda gerçekleşen HOR reaksiyonu şu şekildedir [17]:

$$
\mathrm{H}_{2} \rightarrow 2 \mathrm{H}^{+}+2 \mathrm{e}^{-} \quad\left(\mathrm{E}_{0}=0,00 \mathrm{~V} ; \mathrm{pH}=0\right)
$$

Hidrojenin elektrokimyasal oksidasyonu için en etkili katalizörler platin (Pt) ve paladyum (Pd)'dur [18]. HOR için farklı metaller de yüksek katalitik aktivite göstermesine rağmen, asidik elektrolit ortamında korozyona ve pasifleştirmeye karşı en iyi kararlılığı gösteren katalizörler soy metallerdir. HOR mekanizmasının; asitli elektrolit ortamındaki Pt üzerinde hız belirleyici adım olan hidrojenin ilk ayrışma adsorpsiyonu ile ilerlediği düşünülmektedir. Bu reaksiyonu basit bir yük transferi takip etmektedir [19].

$\mathrm{H}_{2}+2 \mathrm{Pt} \rightarrow 2 \mathrm{Pt}^{-\mathrm{H}_{\text {ads }}}$

$2 \mathrm{Pt}-\mathrm{H}_{\text {ads }} \rightarrow 2 \mathrm{Pt}+2 \mathrm{H}^{+}+2 \mathrm{e}^{-}$

Pt katalizörleri HOR için sergilediği yüksek katalitik aktivite göz önünde bulundurulduğunda, saf hidrojen ile çalışıldığında, çok düşük seviyelerde Pt kullanımı yeterlidir. Hidrojen, PEM yakıt hücreleri için ideal seçim olsa da, saf hidrojen üretimi hala ekonomik değildir. Hidrojen akımı içerisinde bulunabilecek olan azot seyreltme etkisine sahipken, hem $\mathrm{CO}_{2}$ hem de $\mathrm{CO}$, saf Pt katalizörlerini zehirleyerek anot performansını düşürmektedir.

PEM yakıt hücresi uygulamalarının birçoğunda; katot elektrotunda gerçekleşen ORR mekanizması için seçici bir katalizör gerekmediğinden, katot reaksiyonu anottan farklıdır. Saf oksijen yerine hava kullanıldığında dahi, hava içerisinde bulunan diğer bileşenler $\left(\mathrm{N}_{2}, \mathrm{Ar}, \mathrm{CO}_{2}\right)$ sadece seyreltici etki yapar. Buna karşın, yakıt olarak metanol 
kullanıldığında seçici bir katalizör gereklidir, çünkü Pt bazlı katalizörler hem oksijen indirgenmesini hem de metanol oksidasyonunu katalize edebilmekte ve karışık potansiyellere yol açabilmektedir. Sulu ortamda oksijenin indirgenmesi, bir dizi olası reaksiyonla yönetilmektedir. Sulu asit ortamında gerçekleşen reaksiyonlar için termodinamik potansiyeller aşağıda verildiği gibidir.

$$
\begin{array}{ll}
\mathrm{O}_{2}+4 \mathrm{H}^{+}+4 \mathrm{e}^{-} \rightarrow 2 \mathrm{H}_{2} \mathrm{O} & \left(\mathrm{E}_{0}=1,229 \mathrm{~V} @ 25^{\circ} \mathrm{C}\right) \\
\mathrm{O}_{2}+2 \mathrm{H}^{+}+2 \mathrm{e}^{-} \rightarrow \mathrm{H}_{2} \mathrm{O}_{2} & \left(\mathrm{E}_{0}=0,695 \mathrm{~V}\right) \\
\mathrm{O}_{2}+\mathrm{H}^{+}+\mathrm{e}^{-} \rightarrow \mathrm{H}_{2} \mathrm{O} & \left(\mathrm{E}_{0}=-0,046 \mathrm{~V}\right)
\end{array}
$$

Oksijenin dört elektron ile indirgenmesi, $\mathrm{H}_{2} / \mathrm{O}_{2}$ yakıt hücresi için en yüksek hücre voltajını sağladığından, gerçekleştirilmesi gereken en etkili reaksiyondur. Bununla birlikte, bu reaksiyonun düşük polarizasyonlarda elde edilmesinin zor olduğu bulunmuştur. Asidik elektrolitlerin tersinir potansiyel değerinde, kıymetli metallerin en kararlı yüzeyleri bile oksit filmlerle kaplanır. Tek istisna altın (Au)'dır; Au, asit varlığında oksijen indirgemesi için etkin olmayan bir katalizördür. Asidik elektrolit varlığında Pt, Pd ve (rodyum) Rh gibi soy metallerin ve bunların alaşımlarının, oksijen indirgemesi için tercih edilen katalizörler olduğu bulunmuştur. Bununla birlikte bu katalizörlerin en iyisi olan Pt; oksijen indirgemede $\mathrm{H}_{2}$ indirgenmesinden en az $106 \mathrm{kez}$ daha az aktiftir. Bu durum, yüksek düzeyde polarizasyona yol açar ve yakıt hücresi verimliliğinin ana katalitik sınırlamasıdır [17].

Yakıt hücresinde kullanılabilecek katalizörlerde bulunması gereken temel gereksinimler, tepkime için sitelerin yüksek katalitik aktivitesini ve bu sitelerin maksimum sayısını içerir. Yakıt hücresi katalizörlerinden istenen diğer gereksinimler ise; elektriksel iletkenlik, iyonomer ile iyi etkileşim ve reaktanlar, ürünler ve elektrolitler ile temas halinde kararlılık olarak verilebilir.

Bir yakıt hücresinin maksimum verim sağladığından emin olmak için, her iki elektrot tepkimesinin termodinamik potansiyellerine olabildiğince yakın olması gerekir. Yapılan araştırmalar, Pt veya Pt içeren katalizörlerin hem etkinlik hem de kararlılık açısından en etkili katalizör materyalleri olduğunu ortaya çıkarmıştır [17], bu nedenle katalizör tabakası bir yakıt hücresi için maliyetin önemli bir kısmını oluşturur. Katalizör maliyetinin düşürülmesi için bazı çözümlerin öne sürülmesine, araştırma ve geliştirme çalışmalarının uzun yıllardır devam etmesine rağmen platin katalizöre alternatif bir katalizör henüz geliştirilememiştir. PEM yakıt hücresinde (özellikle katot elektrotunda) platin katalizör kullanımı, yüksek maliyetinin yanı sıra çeşitli sıkıntılar ortaya çıkarmaktadır:

- Platin ile katalize edilmiş oksijen indirgeme reaksiyonu 4 elektron reaksiyonu değildir. 2 elektronlu oksijen indirgeme reaksiyonu sonucu oluşan $\mathrm{H}_{2} \mathrm{O}_{2}$ yalnızca sistemin verimini düşürmekle kalmayıp, güçlü oksidasyon kabiliyeti sebebiyle katalizörlerin katalitik aktivitelerini de düşürebilir. Ayrıca hidrojen peroksit radikalleri karbon ta- 
bakasına ve proton değişim membranına zarar vererek bozunmalarına neden olabilir.

- Pt katalizörleri besleme sistemindeki kirleticilere karşı çok hassastır. Hava akımı içerisindeki $\mathrm{NO}_{x}$ ve $\mathrm{SO}_{x}$ gazları, $\mathrm{H}_{2}$ gazı içerisinde bulunabilecek $\mathrm{CO}, \mathrm{H}_{2} \mathrm{~S}, \mathrm{NH}_{3}$, organik sülfür-karbon ve karbon-hidrojen bileşikleri yakıt hücresi performansı için önemlidir. Bu kirlilikler veya kirleticiler Pt katalizörünü kolayca zehirleyebilir, bu da performans düşüşüne neden olur [20].

- Katalizör tabakası ile ilgili bir diğer önemli husus da dayanıklılıklarıdır. Katalizör tabakası, çalışma sırasında malzeme bozulmasına duyarlıdır. Ferreira ve ark., (2005), platin parçacıklarının iyonomer içinde çözündüğünü ve Ostwald olgunlaşması olarak adlandırılan daha büyük parçacıklara dönüştüğünü göstermiştir [21].

- Ayrıca, katalizör tabakasının şişmesinden kaçınmak, optimum PEM yakıt hücresi performansı ve dayanıklılığı için kritik öneme sahiptir. Katalizör tabakasındaki suyun taşınma/buharlaşma mekanizmasının aydınlatılmasına, katalizör tabakasının mikro yapısı ile ıslanabilirliği arasındaki ilişkinin kurulmasına ve gelecek nesiller için yüzey prototiplendirilmesini sağlayacak tatmin edici bir araç geliştirilmesine fazlasıyla ihtiyaç vardır [11].

Yakıt hücresi katalizörlerinin maliyetini düşürecek ve platinin sahip olduğu dezavantajları giderecek katalizörler üretebilmek için iki yaklaşım mevcuttur: Pt olmayan katalizörlerin araştırılması ve kompozit Pt katalizörlerin üretilmesi. PEM yakıt hücresi ORR için en umut veren soy metal katalizörleri olarak, metal/N/C sınıfı katalizörler geniş bir şekilde araştırılmıştır. Yüksek yüzey alanı ve aktif bölgelere erişilebilirlik sağlayan büyük gözeneklerle iyi geliştirilmiş mezo-gözenekli Fe/N/C katalizörleri, hem yarı hücre hem de tek hücreli sistemlerde platin katalizöre kıyasla üstün performans sergilemiştir [22]. Son zamanlarda Pd daha ucuz ve daha bol olması sebebiyle platinin yerini alabilecek muhtemel adaylardan biri olarak görülmektedir. Fe, Ni, Co, $\mathrm{Cu}$ ve Ag gibi farklı metallerle modifiye edilmiş Pd esaslı alaşım katalizörleri saf $\mathrm{Pd}$ katalizörü ile karşılaştırıldığında PEM yakıt hücresinde daha yüksek ORR aktivitesi göstermektedir [23-27]. Metal bazlı olmayan katalizör çalışmalarında ise en dikkat çeken azot katkılı karbon nanofiber (N-CNT) katalizörlerdir. Üretilen bu katalizörler performans ve kararlılık olarak Pt katalizörü geçemese de maliyet açısından umut vaat etmektedir [28]. İstenilen şartları sağlayabilecek yeni bir katalizör üretmek için diğer yaklaşım ise; platin bazlı kompozit katalizörler ( $\mathrm{Pt}_{3} \mathrm{Co}, \mathrm{Pt}-\mathrm{Pd}, \mathrm{Pt} / \mathrm{V}-\mathrm{TiO}_{2}, \mathrm{PtCo}$, $\mathrm{Pt}-\mathrm{TiO}_{2}$ nanotüp) sentezleyerek platin kullanımını azaltmak [29-33] ya da platinin daha etkin bir biçimde yüklenmesi ile yine miktarı ile birlikte maliyetini düşürmektir [34-36].

\subsubsection{Gaz difüzyon tabakası}

Genellikle karbon fiber esaslı gözenekli malzemelerden oluşan gaz difüzyon tabakaları önemli fonksiyonlara sahiptir. Katalizör tabakalarına iletilecek olan reaktant gazlarının homojen bir dağılımını sağlamak, katot katalizör tabakasından bipolar pla- 
kaların gaz kanallarına iletilecek olan ürün suyu ve 1sısı için yollar sağlamak; katalizör tabakalarını elektriksel olarak bipolar plakalara bağlamak ve MEA için mekanik destek sağlamak, gaz difüzyon tabakalarının görevidir [37]. Şimdiye kadar gaz difüzyon tabakaları; polimer bazlı karbon fiber kompozitlerden (karbon kağıdı), karbon kumaştan ve metalik köpüklerden yapılmıştır. En yaygın kullanılan gaz difüzyon tabakaları polimer (fenolik reçine gibi) içeren karbon kâğıtlarıdır. PEM yakıt hücresinin performansı, gaz difüzyon tabakalarının gözenekliliğin büyüklüğüne ve dağılımına ve karbon kağıdının elektrik iletkenliğine büyük ölçüde bağlıdır [38].

Gaz difüzyon tabakasının özellikleri iki tip polarizasyonla ilişkili olabilir. Gaz difüzyon tabakasının elektriksel iletkenliği ohmik polarizasyonu ile; gözeneklilik büyüklüğü ve gözeneklilik dağılımı ise difüzyon polarizasyonu ile ilişkilidir. Gaz difüzyon tabakasının gözenek büyüklügünün azalması bipolar plakalar ile arasındaki temas noktalarının artmasına yol açabilir, bu da ohmik direncin ve ohmik polarizasyonun azalmasına sebep olur. Çünkü, gözenek çapını arttırılması reaktant gazların ve katot katalizörü katmanındaki üretilen suyun geçiş yolunu arttırılmasını sağlar. Artan gözenek büyüklüğü, su taşması olayını engelleyebilir. Bu nedenle, araştırmacılar arasında gaz difüzyon tabakasının gözenek büyüklügüünü artan performansa yol açıp açmadığı henüz bir sorundur. Ohmik polarizasyon, çalışmaların orta akım yoğunluklarına hakimdir ve konsantrasyon polarizasyonu, yüksek akım yoğunluklarına bağlanır. Ancak, azalan ohmik polarizasyonun konsantrasyon polarizasyonundan daha önemli bir konu olduğu vurgulanmalıdır. Çünkü, ohmik direncin akım yoğunluğu alanı çok daha geniştir [38].

Nafion membranın gerekli olan proton iletkenliğini ve mekanik bütünlüğünü korumak için, genellikle nemlendirilmiş gazlar kullanılır. Bununla birlikte fazla su, elektrotlarda su taşmasına yol açarak reaktantların katalizör tabakası aktif bölgelerine erişimini engeller. Suyun uzaklaştırılmasını kolaylaştırmak için, gaz difüzyon tabakaları genellikle politetrafloroetilen (PTFE veya Teflon) [39] veya florlanmış etilen propilen (FEP) gibi maddeler kullanılarak hidrofobik işleme tabi tutulur [40]. Ayrıca, katalizör ve gaz difüzyon tabakası arasına bir mikro gözenekli tabaka yüklenir. Adından da anlaşılacağı gibi, mikro gözenekli tabaka, gaz difüzyon tabakasından (10-100 mm) daha küçük ortalama gözenek boyutuna (1-10 mm) sahiptir ve genellikle hidrofobik bir bağlayıcı ve gözenek oluşturucu madde olarak karbon siyahı kullanılır [41]. Genel olarak, gaz difüzyon tabakasına bir mikro gözenekli tabaka eklenmesiyle, su yönetiminin ve PEM yakıt hücresi performansının iyileştiği gözlenmiştir. Mikro gözenekli tabakanın, katalizör ve gaz difüzyon tabakası arasında, suyun katottan anot tarafına taşınmasına neden olan ve membranın hidratasyon seviyesini geliştiren, kılcal bir bariyer oluşturduğu belirlenmiştir [42]. Mikro gözenekli tabakanın aynı zamanda, hücrenin su taşkını toleransını daha da arttırarak buhar formundaki suyun geçişine izin vermesiyle, katalizör ve gaz difüzyon tabakası arasında bulunan ara yüzey boşluğundaki su birikimini de ortadan kaldırdığı belirtilmiştir [43]. Ayrıca mikro gözenekli tabakada bulunan çatlakların; gaz difüzyon tabakasına olan su girişlerinin sayısını 
sınırladığı, su yollarını kararlı hale getirdiği ve dolayısıyla su doygunluğunu azalttığı belirlenmiştir [44]. Ek olarak, mikro gözenekli tabakanın elektrik iletkenliği arttırmasının yanı sıra ve gaz difüzyon tabakası fiberlerinin katalizör tabakasına girişini önlediği belirtilmiştir [41].

Gaz difüzyon tabakası, katalizör tabakalarının dış tarafında bulunan makro gözenekli ve elektrik iletken bir malzemedir. Birincil işlevi, reaktantların ve ürünlerin katalizör tabakasına ve buradan taşınmasını sağlamaktır ve bu nedenle yakıt hücresindeki reaktant gaz dağılımı ve su yönetiminde önemli bir rol oynar. Gaz difüzyon tabakası ayrıca; elektronların katalizör tabakasına ve katalizör tabakasından iletilmesi, istenen çalışma sıcaklığını korumak için atık ısının katalizör tabakasından bipolar plakaya iletilmesi ve katalizör tabakasına ve membrana mekanik destek sağlanması gibi önemli fonksiyonlara sahiptir. Bu fonksiyonları yerine getirmek için gaz difüzyon tabakası; gözenekli, kısmen hidrofobik, sert ve yüksek elektriksel ve termal iletkenliğe sahip olmalidir [45].

Gaz difüzyon tabakası, PEM yakıt hücrelerinin su yönetiminde hayati bir rol oynamaktadır. Bu nedenle, gaz difüzyon tabakalarının yapılarını ve özelliklerini optimize etmek ve bunu başarmak için yöntemleri anlamak, yakıt hücrelerinin performansını artırmaya ve dengelemeye yardımcı olur. Gaz difüzyon tabakasının su yönetimini geliştirmek için farklı yöntemler uygulanmakta olup, bunlar arasında ve bunlarla sınırlı olmamak üzere perforaj, PTFE kaplama ve gaz difüzyon tabakası yüzeyine mikro gözenekli tabaka uygulanması gibi yapısal modifikasyonlar yer almaktadır [46]. Bunun yanı sıra, gaz difüzyon tabakasının elektriksel ve 1sıl iletkenliğini geliştirmek için yapılan çalışmalar da halen güncelliğini korumaktadır [47-49]. Ayrıca, gaz difüzyon tabakası üretiminde karbon dışındaki malzemelerin (metal, seramik vb.) kullanımı da ilgi çeken konular arasındadır [45, 50].

\subsubsection{Bipolar plaka}

PEM yakıt hücrelerinin bir diğer önemli bileşeni, bipolar plakalardır. Bipolar plakalar; yakıt hücresi yığınlarında hücreden hücreye elektrik bağlantısının sağlanmasında, reaktant gazların akış alanı boyunca homojen olarak dağıtılmasında, elektrik akımının her hücreden iletilmesinde, hücrenin çıkışındaki ürün suyunun uzaklaştırılmasında ve reaksiyonlar sonucu oluşan ısının hücreden uzaklaştırılmasında görev almaktadır [51]. PEM yakıt hücresinin tüm bileşenleri göz önüne alındığında bipolar plakalar, en hacimli ve ağır bileşendir (toplam ağırlığın yaklaşık \% 80'i). Aynı zamanda en pahalı parçalardan (yığın maliyetinin yaklaşık \% 40’1) biri olan bipolar plakalar PEM yakıt hücresi uygulamalarını olumsuz yönde etkilemektedir [52].

Enerji departmanının (Department of Energy, DOE) kriterlerine göre bipolar plakalar; düzlemsel elektriksel iletkenlik $\left(>100 \mathrm{Scm}^{-1}\right)$, ara yüz temas direnci $\left(<30 \mathrm{~m} \Omega \mathrm{cm}^{2}\right)$, hafif asidik suda $(\mathrm{pH}<4)$ kimyasal kararlılık, korozyon direnci $\left(<16 \mu \mathrm{Acm}^{-2}\right)$, yüksek termal iletkenlik $\left(>10 \mathrm{~W}(\mathrm{mK})^{-1}\right)$, hidrojen ve oksijenin düşük geçirgenliği $\left(<2 \times 10^{-6}\right.$ 
$\left.\mathrm{cm}^{3}\left(\mathrm{~cm}^{2} \mathrm{~s}\right)^{-1}\right)$, eğilme dayanımı (> $\left.59 \mathrm{MPa}\right)$ ve darbe dayanımı $\left(>40,5 \mathrm{Jm}^{-1}\right)$ özelliklerini sağlamalıdır [53].

Bipolar plakaların üretimi için yaygın olarak kullanılan iki ana malzeme ailesi vardır; grafit ve metaller. Yüksek maliyetine rağmen katı grafit; korozyon direnci, kimyasal inertliği ve iyi iletkenliği nedeniyle laboratuvar ölçekli çalışmalarda yaygın olarak kullanılmaktadır. Bununla birlikte, akış kanallarının grafit bipolar plaka yüzeyi üzerine işlenmesi veya elektrokimyasal olarak kazılması gerekmektedir. $\mathrm{Bu}$ durum ise grafitin seri üretimde kullanımını sınırlamaktadır. Grafitin aksine metal bipolar plakalar; hafif ve taşınabilir yakıt hücresi yı̆̆ınlarının seri üretiminde çok ince tabakalarda üretim için uygundur [54]. Bipolar plakalar; mükemmel şekillendirilebilirlikleri, nispeten yüksek mukavemeti, yüksek elektriksel iletkenliği ve düşük gaz geçirgenliği, ve aynı zamanda çok yüksek hacimsel ve gravimetrik güç yoğunluklarına sahip yakıt hücrelerinin seri üretimi için makul maliyetleri nedeniyle metalik plakalardan kolaylıkla yapılabilir [52]. Bugüne kadar; paslanmaz çelik [55], titanyum [56], alüminyum [57], bakır [58] gibi metalik malzemeler bipolar plaka yapımında kullanılmıştır. Ancak metalik malzemeler; $\mathrm{SO}_{4}^{-2}, \mathrm{~F}^{-}$ve $\mathrm{Cl}^{-}$iyonlarını içeren zayıf asidik bir ortam olan PEM yakıt hücresi çalışma ortamında çözünmeye maruz kalabilir. Kaplamalar ve yüzey işlemleri yoluyla yüzey modifikasyonu, PEM yakıt ortamlarında metalik malzemelerin korozyon direncini ve yüzey iletkenliğini arttırmak için yaygın olarak benimsenmiştir. Buna göre, temel olarak metal bazlı ve karbon bazlı kaplamalar halinde gruplandırılan çeşitli kaplamaların ve işlemlerin performansı incelenmiştir [59]. Ayrıca; polipirol, polianilin veya bunların türevleri gibi iletken polimerler de, esas olarak mükemmel kimyasal ve fiziksel kararlılıkları ve yüksek elektrik iletkenliklerine bağlı olarak korozyona karşı metal koruma adayları olarak kabul edilmektedir [52].

\subsection{Uygulama Alanları}

İşlevsel bir yakıt hücresine yol açan araştırma ve geliştirme çalışmaların başlangıcı 1800'lü yılların başına kadar uzanır. Kimyager ve patent avukatı Sir William Grove, ünlü su elektrolizörü/yakıt hücresi deneysel gösterimi nedeniyle yakıt hücresi biliminin babası olarak kabul edilmektedir. Sir William Grove, elektriğin üretilmesinde kullanılabilecek ters bir süreci kavramsallaştırmak için elektroliz teorisini kullanmıştır. Bu hipoteze dayanarak Grove, elektrik üretmek için hidrojen ve oksijeni birleştiren bir sistem (elektrik kullanarak ayırmak yerine) geliştirmeyi başarmıştır. Orijinalinde bir gaz pili olarak tanımlanan sistem, zamanla yakıt hücresi olarak bilinmeye başlamıştır. Yakıt hücresi ile yapılan araştırmalar devam ederken 1959 yılında, bir İngiliz mühendis olan Francis Thomas Bacon, kullanıma hazır ilk yakıt hücresini geliştirmiştir. Yaptığ 1 bu çalışma NASA tarafından lisans verilecek ve benimsenecek kadar etkileyici olmuştur. Özellikle PEM ve alkali yakıt hücreleri, NASA tarafindan 1960'larda Gemini ve Apollo insanlı uzay programlarının bir parçası olarak uygulanmıştır. NASA yakıt hücreleri ticari olmayan ve çeşitli sıkıntıları deneyimleyerek isteğe göre uyarlanmış, yakıt ve oksidant olarak sırasıyla hidrojen 
ve oksijen kullanılmıştır. Günümüzde yakıt hücreleri; taşımacılık, sabit ve taşınabilir uygulamalarda kullanılmakta, kademeli olarak kamu ve özel sektör tarafindan benimsenmekte ve uzun vadeli uygulamalar için daha güvenilir ve dayanıklı hale gelmektedir [60].

Sera gazı emisyonlarının kontrol edilebilirliği gibi çevre üzerindeki potansiyel etkilerinden dolayı PEM yakıt hücrelerinin ana uygulamaları, öncelikle taşımacılık alanına yoğunlaşmıştır. PEM yakıt hücrelerinin diğer uygulamaları da dağınık/sabit ve taşınabilir güç uygulamaları olarak verilebilir. Diğer yakıt hücreleri ile karşılaştırıldığında sahip olduğu yüksek güç yoğunluğu ve üstün dinamik karakteristikleri nedeniyle PEM yakıt hücreleri birçok ana motor üretim firmaları tarafından yoğun bir biçimde çalışılmaktadır. Yakıt hücreli taşıtlara; GM Hydrogen 1 (Zafira), Ford Demo IIa (Focus), DaimlerChrysler NeCar4a, Honda FCX-V3, Toyota FCHV-4, Nissan XTERRA FCV, VW Bora HyMotion ve Hyundai Santa Fe FCV modelleri örnek olarak verilebilir. Dağınık PEM yakıt hücresi güç sistemi uygulamalarına temel olarak küçük çapta odaklanılmıştır (merkezi olmayan kullanım için 50-250 kW veya haneler için $<10$ kW). Yakıt hücrelerinin atık ısının da kullanılabilir olması, dağınık güç uygulamaları için tasarlanan yakıt hücresi sistemlerinin verimini önemli ölçüde arttırmaktadır. Bankalar ve telekomünikasyon şirketleri için yedek güç, elektrik kesintilerinde ortaya çıkan yüksek maliyet nedeniyle oldukça önem taşımaktadır. Plug Power GenSys ve Ballard FCgen ${ }^{\mathrm{TM}} 1020$ ACS yakıt hücresi sistemleri gibi birçok ünite geliştirilmiş ve birçok yerde konuşlandırılmıştır. Gelecek vaat eden bir diğer alan ise, pillerin sınırlı enerji kapasitesinin, dizüstü bilgisayarlar, cep telefonları ve askeri telsiz/iletişim cihazları gibi modern taşınabilir elektrikli cihazların hızla artan enerji ihtiyacını karşılamadığını göz önüne alarak taşınabilir güç kaynağıdır. PEM yakıt hücreleri, hidrojen yakıtı mevcut olduğu sürece sürekli güç sağlar ve verimlilik kaybı olmadan küçük boyutlarda üretilebilirler. Toshiba, Sony, Motorola, LG ve Samsung gibi başlıca elektronik şirketlerinde, taşınabilir yakıt hücreleri için şirket içi Ar-Ge birimleri bulunmaktadir [11].

Dünyada PEM yakıt hücrelerinin ticarileşmesi henüz gelişmemiştir. Bunun önündeki en büyük iki engel, kullanım ömrü ve maliyettir. MEA (membran elektrot bileşkesi) gibi yakıt hücresi bileşenleri, uzun süreli işlemler sırasında bozulmaya uğramaktadır. Ticari bir yakıt hücresinin ihtiyaç duyduğu kullanım ömrü, hafif araçlar için 5000 çalışma saatinin üzerinde ve \% 10 performans düşüşü ile sabit enerji üretimi için 40.000 saatin üzerindedir. Şu anda, çoğu yakıt hücresi yaklaşık bin saatlik çalışmadan sonra büyük bir performans düşüşü sergilemektedir. Enerji departmanının (DOE) verilerine göre; PEM yakıt hücresi bileşenleri için 2015 yılında ulaşılan maliyet $17 \$ / \mathrm{kW}_{\text {net }}$ ve kullanım ömrü 2500 saat olmakla birlikte, 2020 hedefleri sırasıyla $14 \$ / \mathrm{kW}_{\text {net }}$ ve 5000 saat olarak belirlenmiştir [61]. Ayrıca DOE; yakıt hücresi sistemleri ve taşımacılık uygulamaları için üretilen yığınlarda 2015 yılı için \% 60 verimle 3900 saat kullanım ömrü ve $53 \$ / \mathrm{kW}_{\text {net }}$ maliyete ulaşıldığını bildirmiş, ayrıca 2020 hedeflerinin \% 65 verimle 5000 saat kullanım ömrü ve maliyeti $40 \$ / \mathrm{kW}_{\text {net }}$ olarak vermiştir [62]. 


\section{SONUÇ VE TARTIŞMA}

İlerleme daima enerji gerektirir. Günümüzde, enerji ihtiyaçları fosil yakıtların yakılmasıyla sağlanmış ve bu da hava kirliliğini ve sera gazı emisyonlarını artırmıştır. Sonuç olarak, sera gazı emisyon problemi, geleneksel tesislerin yüksek verimli tasarımını teşvik etmek için somut bir firsat sunabilecek, aynı zamanda enerji sistemlerine yeni bir yaklaşım ve bunun sonucu olarak da ileri teknolojilerin yayılmasını sağlayabilecek kadar önem taşımaktadır. En ümit verici enerji dönüşüm teknolojilerinden biri, yakıt hücresidir çünkü yakıt hücresi; kimyasal enerjinin, düşük çevresel etki ile doğrudan elektrik enerjisine dönüştürüldüğü bir elektrokimyasal cihazdır. PEM yakıt hücreleri, büyük kirleticilerde $>\% 90$ azalma ile birlikte, elektrik enerjisi dönüşümünde \% 60'a veya elektrik ve termal enerjinin birlikte üretildiği kojenerasyon sistemlerinde \% 80'e varan potansiyele sahiptir. Çalışma süresi ve maliyet, PEM yakıt hücrelerinin ticarileşmesinin önündeki en büyük engellerdir. PEM yakıt hücrelerinin kullanımının yaygınlaşması için, var olan engellerin üstesinden gelmek için temel atılımlara ihtiyaç vardır. Özellikle yakıt hücresi bileşenlerinin (katalizör, membran, MEA, bipolar tabaka) iyileştirilmesi, istenilen özellikleri karşılayacak daha az maliyetli alternatif malzemelerin tanımlanması ve geliştirilmesine ihtiyaç vardır. Bunun yanı sıra, yakıt hücresinin çalışması esnasında karşılaşılan durumlar (su davranışı, hidrofobiklik/hidrofiliklik, mikro-mini kanalların varlığı, polarizasyonlar, korozyon dirençleri vb.) ile ilgili temel bilgilerin edinilerek analitik modellerin ve deneysel araçların da geliştirilmesi gerekmektedir. Mevcut derleme çalışmasında, PEM yakıt hücrelerinin teorisi detaylı bir biçimde incelenmiş, tüm bileşenlerinin gereklilikleri verilerek yapılan çalışmalar özetlenmiş ve uygulama alanları ile gelecek performans beklentileri verilmiştir.

\section{SEMBOLLER}

Ag Gümüş

Ar Argon

$\mathrm{Au} \quad$ Altın

Co Cobalt

CO Karbon monoksit

$\mathrm{CO}_{2} \quad$ Karbon dioksit

$\mathrm{Cu}$ Bakitr

$\mathrm{e}^{-} \quad$ Elektron

E Termodinamik potansiyel

$\mathrm{E}^{0} \quad$ Tersinir standart potansiyel

E $_{\text {PEM }} \quad$ Termodinamik verimlilik

F Faraday sabiti 
$\mathrm{Fe} \quad$ Demir

$\Delta \mathrm{G}^{0} \quad$ Gibbs serbest enerjisindeki değişim

$\mathrm{H}^{+} \quad$ Proton

$\mathrm{H}_{2} \quad$ Hidrojen gazı

$\mathrm{H}_{2} \mathrm{O} \quad$ Su molekülü

$\mathrm{H}_{2} \mathrm{O}_{2} \quad$ Hidrojen peroksit

$\mathrm{H}_{2} \mathrm{~S} \quad$ Hidrojen sülfür

I Hücre akımı

$\mathrm{LHV}_{\mathrm{H} 2}$ Hidrojenin alt 1sıl değeri

$\mathrm{m}_{\mathrm{H} 2} \quad$ Hidrojen tüketim miktarı

$\mathrm{MW}_{\mathrm{H} 2} \quad$ Hidrojenin molekül ağırlığ1

n Elektron sayısı

$\mathrm{NH}_{3} \quad$ Amonyak

Ni Nikel

$\mathrm{O}_{2} \quad$ Oksijen gazı

$\mathrm{P}_{\mathrm{H} 2 \mathrm{O}} \quad$ Suyun k1smi basinc1

$\mathrm{P}_{\mathrm{H} 2} \quad$ Hidrojenin k1smi basınc1

$\mathrm{P}_{\mathrm{O} 2} \quad$ Oksijenin k1smi basınc1

Pd Paladyum

Pt Platin

R Gaz sabiti

$\mathrm{Rh} \quad$ Rodyum

$\mathrm{SiO}_{2} \quad$ Silisyum dioksit

T Hücre sıcaklığı

$\mathrm{TiO}_{2} \quad$ Titanyum dioksit

W Güç

$\mathrm{V}_{\text {hücre }} \quad$ Hücre potansiyeli

$\mathrm{ZrO}_{2} \quad$ Zirkonyum dioksit

$\eta_{\text {akt }} \quad$ Aktivasyon polarizasyonu

$\eta_{\text {dif }} \quad$ Difüzyon polarizasyon

$\eta_{\text {ohm }} \quad$ Ohmik polarizasyonu

\section{KAYNAKÇA}

1. Farooqui, U.R., Ahmad, A.L., Hamid, N.A., 2018. “Graphene Oxide: A Promising Memb- 
rane Material for Fuel Cells,” Renewable and Sustainable Energy Reviews, 82, 714-33.

2. Lucia, U. 2014. “Overview on Fuel Cells," Renewable and Sustainable Energy Reviews, 30, 164-169.

3. Haque, M.A., Sulong, A.B., Loh, K.S., Majlan, E.H., Husaini, T., Rosli, R.E. 2017. "Acid Doped Polybenzimidazoles Based Membrane Electrode Assembly for High Temperature Proton Exchange Membrane Fuel Cell: A Review," International Journal of Hydrogen Energy, 42(14), 9156-79.

4. Wang, Y., Leung, D.Y.C., Xuan, J., Wang, H. 2016. “A Review on Unitized Regenerative Fuel Cell Technologies, Part-A : Unitized Regenerative Proton Exchange Membrane Fuel Cells," Renewable and Sustainable Energy Reviews, 65, 961-77.

5. Park, J.-S., Shin, M.-S., Kim, C.-S. 2017. "Proton Exchange Membranes for Fuel Cell Operation at Low Relative Humidity and Intermediate Temperature : An Updated Review," Current Opinion in Electrochemistry, 5(1), 43-55.

6. Bakangura, E., Wu, L., Ge, L., Yang, Z., Xu, T. 2016. "Mixed Matrix Proton Exchange Membranes for Fuel Cells : State of the Art and Perspectives," Progress in Polymer Science, 57, 103-52.

7. Authayanun, S., Im, K., Arpornwichanop, A. 2015. "A Review of the Development of High Temperature Proton Exchange Membrane Fuel Cells," Chinese Journal of Catalysis, 36(4), 473-83.

8. Kraytsberg, A., Ein-Eli, Y. 2014. "Review of Advanced Materials for Proton Exchange Membrane Fuel Cells," Energy and Fuels, 28(12), 7303-30.

9. Al-baghdadi, M.A.R.S., ve Al-janabi, H.A.K.S. 2005. "Optimization Study of Proton Exchange Membrane Fuel Cell Performance," Turkish Journal of Engineering and Environmental Sciences 29, 235-240.

10. Arshad, A., Muhammed Ali, H., Habib, A., Bashir, M.A., Jabbal, M., Yan, Y. 2019. "Energy and Exergy Analysis of Fuel Cells: A review," Thermal Science and Engineering Progress, 9, 308-321.

11. Wang, Y., Chen, K.S., Mishler, J., Cho, S.C., Adroher, X.C. 2011. “A Review of Polymer Electrolyte Membrane Fuel Cells: Technology, Applications, and Needs on Fundamental Research," Applied Energy, 88(4), 981-1007. 030.

12. Peighambardoust, S.J., Rowshanzamir, S., Amjadi, M. 2010. "Review of the Proton Exchange Membranes for Fuel Cell Applications," International Journal of Hydrogen Energy, 35, 9349-84.

13. Bae, I., Oh, K.H., Yun, M., Kang, M.K., Song, H.H., Kim, H. 2018. "Nanostructured Composite Membrane with Cross-Linked Sulfonated Poly(Arylene Ether Ketone)/Silica for High-Performance Polymer Electrolyte Membrane Fuel Cells under Low Relative Humidity," Journal of Membrane Science, 549, 567-74.

14. Xu, X., Li, R., Tang, C., Wang, H., Zhuang, X., Liu, Y., Kang, W., Shi, L. 2018. "Cellulose Nanofiber-Embedded Sulfonated Poly (Ether Sulfone) Membranes for Proton 
Exchange Membrane Fuel Cells," Carbohydrate Polymers, 184, 299-306.

15. Demirci, A. 2006. "Borik Asit Katkılı Sülfolanmış Polisitiren Membranın Polimer Elektrolit Yakıt Hücresinde Elektrolit Olarak Kullanılabilirliği,” Yüksek Lisans Tezi, Gazi Üniversitesi, Ankara.

16. Ni, C., Wei, Y., Zhao, Q, Liu, B., Sun, Z., Gu, Y., Zhang, M., Hu, W. 2018. "Novel Proton Exchange Membranes Based on Structure-Optimized Poly(Ether Ether Ketone Ketone)s and Nanocrystalline Cellulose," Applied Surface Science, 434, 163-75.

17. Thompsett, D. 2003. "Catalysts for the Proton Exchange Membrane Fuel Cell," In CRC Press, 2-12.

18. Markovic, N.M., Grgur, B.N., Ross., P.N. 1997. "Temperature-Dependent Hydrogen Electrochemistry on Platinum Low-Index Single-Crystal Surfaces in Acid Solutions," The Journal of Physical Chemistry, 101(27), 5405-13.

19. Bai, L., Harrington, D.A., Conway, B.E. 1987. "Behavior of Overpotential—deposited Species in Faradaic Reactions-II. Ac Impedance Measurements on $\mathrm{H}_{2}$ Evolution Kinetics at Activated and Unactivated Pt Cathodes," Electrochimica Acta, 32, 1713-31.

20. Zhang, L., Zhang, J., Wilkinson, D.P., Wang, H. 2006. "Progress in Preparation of Non-Noble Electrocatalysts for PEM Fuel Cell Reactions," Journal of Power Sources, 156(2), 171-82.

21. Ferreira, P.J., La, Q, G.J., Shao-Horn, Y., Morgan, D., Makharia, R., Kocha, S., Gasteiger, H.A. 2005. "Instability of Pt/C Electrocatalysts in Proton Exchange Membrane Fuel Cells A Mechanistic Investigation," Journal of Electrochemical Society, 152(11), 2256-71.

22. Mun, Y., Kim, M.J., Park, S.-A., Lee, E., Ye, Y., Lee, S., Kim, Y.-T., Kim, S., Kim, O.-H., Cho, Y.-H., Sung, Y.-E., Lee, J. 2018. "Soft-Template Synthesis of Mesoporous Non-Precious Metal Catalyst with Fe-Nx/C Active Sites for Oxygen Reduction Reaction in Fuel Cells," Applied Catalysis B: Environmental, 222, 191-99.

23. Boone, C.V., Maia, G. 2017. "Pt-Pd and Pt-Pd-(Cu or Fe or Co)/Graphene Nanoribbon Nanocomposites as Efficient Catalysts toward the Oxygen Reduction Reaction," Electrochimica Acta, 247, 19-29.

24. Park, K., Matsune, H., Kishida, M., Takenaka, S. 2017. "Carbon-Supported Pd-Ag Catalysts with Silica-Coating Layers as Active and Durable Cathode Catalysts for Polymer Electrolyte Fuel Cells," International Journal of Hydrogen Energy, 42(30), 1895158.

25. Takenaka, S., Miyata, H., Tsukamoto, T., Matsune, H., Kishida, M. 2012. "Improvement in Activity of Highly Durable Silica-Coated Pd/CNT Cathode Catalysts for PEFC by Addition of $\mathrm{Cu}$," ECS Transactions, 50, 1715-22.

26. Takenaka, S., Tsukamoto, T., Matsune, H., Kishida, M. 2013. "Carbon NanotubeSupported Pd-Co Catalysts Covered with Silica Layers as Active and Stable Cathode Catalysts for Polymer Electrolyte Fuel Cells," Catalysis Science Technoly, 3, $2723-31$. 
27. Zhao, J., Sarkar, A., Manthiram, A. 2010. "Synthesis and Characterization of Pd-Ni Nanoalloy Electrocatalysts for Oxygen Reduction Reaction in Fuel Cells," Electrochimica Acta, 55, 1756-65.

28. Bokach, D., Hoopen, S., Muthuswamy, N., Buan, M.E.M., Ronning, M. 2016. "Nitrogen-Doped Carbon Nanofiber Catalyst for ORR in PEM Fuel Cell Stack: Performance, Durability and Market Application Aspects," International Journal of Hydrogen Energy, 41(39), 17616-30.

29. Bharti, A., Cheruvally, G. 2017. "V-Doped $\mathrm{TiO}_{2}$ supported Pt as a Promising Oxygen Reduction Reaction Catalyst: Synthesis, Characterization and in-Situ Evaluation in Proton Exchange Membrane Fuel Cell,” Journal of Power Sources, 363, 413-21.

30. Egetenmeyer, A., Radev, I., Durneata, D., Baumgartner, M., Peinecke, V., Natter, H., Hempelmann, R. 2017. "Pulse Electrodeposited Cathode Catalyst Layers for PEM Fuel Cells," International Journal of Hydrogen Energy, 42(19), 13649-60.

31. Xiong, X., Chen, W., Wang, W., Li, J., Chen, S. 2017. "Pt-Pd Nanodendrites as Oxygen Reduction Catalyst in Polymer-Electrolyte-Membrane Fuel Cell," International Journal of Hydrogen Energy, 42(40), 25234-43.

32. Zeng, Y., Shao, Z., Zhang, H., Wang, Z., Hong, S., Yu, H., Yi, B. 2017. "Nanostructured Ultrathin Catalyst Layer Based on Open-Walled PtCo Bimetallic Nanotube Arrays for Proton Exchange Membrane Fuel Cells," Nano Energy, 34, 344-55.

33. Zhang, C., Yu, H., Fu, L., Xiao, Y., Gao, Y., Li, Y., Zeng, Y., Jia, J., Yi, B., Shao, Z. 2015. "An Oriented Ultrathin Catalyst Layer Derived from High Conductive TiO2 Nanotube for Polymer Electrolyte Membrane Fuel Cell," Electrochimica Acta, 153, 361-69.

34. Breitwieser, M., Klingele, M., Britton, B., Holdcroft, S., Zengerle, R., Thiele, S. 2015. "Improved Pt-Utilization Efficiency of Low Pt-Loading PEM Fuel Cell Electrodes Using Direct Membrane Deposition,” Electrochemistry Communications, 60, 168-71.

35. Daş, E., Alkan Gürsel, S., Işıkel Şanlı, L., Bayrakçeken Yurtcan, A. 2017. "Thermodynamically Controlled Pt Deposition over Graphene Nanoplatelets: Effect of Pt Loading on PEM Fuel Cell Performance,” International Journal of Hydrogen Energy, 42(30), 19246-56.

36. Wang, L., Wurster, P., Gazdzicki, P., Roussel, M., Sanchez, D.G., Guetaz, L., Jacques, P. A., Gago, A. S., Friedrich, K. A. 2018. "Investigation of Activity and Stability of Carbon Supported Oxynitrides with Ultra-Low Pt Concentration as ORR Catalyst for PEM Fuel Cells," Journal of Electroanalytical Chemistry, 819, 312-21.

37. Ferreira, R. B, Falcão, D. S., Oliveira, V. B., Pinto, A. M. F. R. 2017. "Experimental Study on the Membrane Electrode Assembly of a Proton Exchange Membrane Fuel Cell: Effects of Microporous Layer, Membrane Thickness and Gas Diffusion Layer Hydrophobic Treatment," Electrochimica Acta, 224, 337-45.

38. Taherian, R., Ghorbani, M.M., Kiahosseini, S.R. 2018. "A New Method for Optimal Fabrication of Carbon Composite Paper as Gas Diffusion Layer Used in Proton Exchange Membrane of Fuel Cells,” Journal of Electroanalytical Chemistry, 815, 90-97. 
39. Park, S., Lee, J.-W., Popov, B.N. 2008. "Effect of PTFE Content in Microporous Layer on Water Management in PEM Fuel Cells," Journal of Power Sources, 177, 457-63.

40. Lim, C., Wang, C.Y. 2004. "Effects of Hydrophobic Polymer Content in GDL on Power Performance of a PEM Fuel Cell," Electrochimica Acta, 49: 4149-56.

41 Jayakumar, A., Sethu, S.P., Ramos, M., Robertson, J., Al-Jumaily, A. 2015. “A Technical Review on Gas Diffusion, Mechanism and Medium of PEM Fuel Cell,” Ionics, 21, $1-18$.

42. Weber, A.Z., Newman, J. 2005. "Effects of Microporous Layers in Polymer Electrolyte Fuel Cells," Journal of Electrochemical Society, 152, A667-68.

43. Tabe, Y., Aoyama, Y., Kadowaki, K., Suzuki, K., Chikahisa, T. 2015. "Impact of Microporous Layer on Liquid Water Distribution at the Catalyst Layer Interface and Cell Performance in a Polymer Electrolyte Membrane Fuel Cell," Journal of Power Sources, 287, 422-30.

44. Lu, Z., Daino, M.M., Rath, C., Kandlikar, S.G. 2010. "Water Management Studies in PEM Fuel Cells, Part III: Dynamic Breakthrough and Intermittent Drainage Characteristics from GDLs with and without MPLs," International Journal of Hydrogen Energy, 35, 4222-33.

45. Hussain, N., Steen, E.V., Tanaka, S., Levecque, P. 2017. "Metal Based Gas Diffusion Layers for Enhanced Fuel Cell Performance at High Current Densities," Journal of Power Sources, 337, 18-24.

46. Omrani, R., Shabani, B. 2017. "Gas Diffusion Layer Modifications and Treatments for Improving the Performance of Proton Exchange Membrane Fuel Cells and Electrolysers: A Review," International Journal of Hydrogen Energy, 42(47), 28515-36.

47. Hao, J., Yu, S., Jiang, Y., Li, X., Shao, Z., Yi, B. 2015. “Antimony Doped Tin Oxide Applied in the Gas Diffusion Layer for Proton Exchange Membrane Fuel Cells," Journal of Electroanalytical Chemistry, 756, 201-6.

48. Sadeghi, E., Djilali, N., Bahrami, M. 2011. "Effective Thermal Conductivity and Thermal Contact Resistance of Gas Diffusion Layers in Proton Exchange Membrane Fuel Cells. Part 1: Effect of Compressive Load,” Journal of Power Sources, 196(1), 246-54.

49. Sadeghifar, H., Djilali, N., Bahrami, M. 2014. "Effect of Polytetrafluoroethylene (PTFE) and Micro Porous Layer (MPL) on Thermal Conductivity of Fuel Cell Gas Diffusion Layers: Modeling and Experiments," Journal of Power Sources, 248, 632-41.

50. Antolini, E., Gonzalez, E. R. 2009. "Ceramic Materials as Supports for Low-Temperature Fuel Cell Catalysts,” Solid State Ionics, 180, 746-63.

51 . Jin, J., Zheng, D., Liu, H. 2017. "The Corrosion Behavior and Mechanical Properties of CrN/Ni-P Multilayer Coated Mild Steel as Bipolar Plates for Proton Exchange Membrane Fuel Cells," International Journal of Hydrogen Energy, 42(48), 28883-97.

52. Pan, T.J., Zuo, X.W., Wang, T., Hu, J., Chen, Z.D., Ren, Y. J. 2016. "Electrodeposited Conductive Polypyrrole/Polyaniline Composite Film for the Corrosion Protection 
of Copper Bipolar Plates in Proton Exchange Membrane Fuel Cells," Journal of Power Sources, 302, 180-88.

53. Taherian, R. 2014. "A Review of Composite and Metallic Bipolar Plates in Proton Exchange Membrane Fuel Cell: Materials, Fabrication, and Material Selection," Journal of Power Sources, 265, 370-90.

54. Kahraman, H. ve Orhan, M.F. 2017. "Flow Field Bipolar Plates in a Proton Exchange Membrane Fuel Cell: Analysis \& Modeling,” Energy Conversion and Management, 133, 363-84.

55. Davies, D.P., Adcock, P.L., Turpin, M., Rowen, S. J. 2000. "Stainless Steel as a Bipolar Plate Material for Solid Polymer Fuel Cells," Journal of Power Sources, 86(1), $237-42$.

56. Wang, S.H., Peng, J., Lui, W.B. 2006. "Surface Modification and Development of Titanium Bipolar Plates for PEM Fuel Cells,” Journal of Power Sources, 160(1), 485-89.

57. Joseph, S., McClure, J.C., Sebastian, P.J., Moreira, J., Valenzuela, E. 2008. "Polyaniline and Polypyrrole Coatings on Aluminum for PEM Fuel Cell Bipolar Plates," Journal of Power Sources, 177(1), 161-66.

58. Nikam, V.V., Reddy, R.G. 2005. "Corrosion Studies of a Copper-Beryllium Alloy in a Simulated Polymer Electrolyte Membrane Fuel Cell Environment," Journal of Power Sources, 152(1-2), 146-55.

59. Oladoye, A.M., Carton, J.G., Benyounis, K., Stokes, J., Olabi, A.G. 2016. "Optimisation of Pack Chromised Stainless Steel for Proton Exchange Membrane Fuel Cells Bipolar Plates Using Response Surface Methodology,” Surface and Coatings Technology, 304, 384-92.

60. Sharaf, O.Z., Orhan, M.F. 2014. "An Overview of Fuel Cell Technology: Fundamentals and Applications," Renewable and Sustainable Energy Reviews, 32, 810-53.

61. https://www.energy.gov/eere/fuelcells/doe-technical-targets-polymer-electrolytemembrane-fuel-cell-components

62. https://www.energy.gov/eere/fuelcells/doe-technical-targets-fuel-cell-systems-andstacks-transportation-applications 